\title{
Fusarium oxysporum f. sp. cubense biocontrol mediated by Bacillus spp. in Prata-Anã banana
}

\author{
Lara Cristine da Silva Vieira ${ }^{1} \oplus$, Shirley Nascimento Costa $^{2} \odot$, Cristine Vanz Borges ${ }^{1} \oplus$, \\ Zalmar Santana Gonçalves ${ }^{3}$, , Fernando $\operatorname{Haddad}^{3}{ }^{\circ}$

\footnotetext{
${ }_{1}^{1}$ Faculdade Maria Milza, Governador Mangabeira, BA, Brasil. E-mail: larinha_cristine@outlook.com; cristine.vanzb@gmail.com

${ }^{2}$ Faculdade Santo Antônio, Alagoinhas, BA, Brasil. E-mail: shirleykosta@gmail.com

${ }^{3}$ Embrapa Mandioca e Fruticultura, Cruz das Almas, BA, Brasil. E-mail: zalmarufrb@hotmail.com; fernando.haddad@embrapa.br
}

ABSTRACT: The aim of this study was to evaluate the controlling effect of Bacillus spp. on Fusarium oxysporum f. sp. cubense (Foc) activity under greenhouse conditions. Two experiments were set up, with the first consisting of one Bacillus application on the substrate, with Foc addition seven days later; two Bacillus applications at a seven-day interval on the substrate and Foc application seven days after the last Bacillus application; and Bacillus applied to the substrate at the same time as Foc. After 14 days of incubation of the substrate infested with Foc and Bacillus, banana seedlings of the Prata-Anã cultivar were planted in tubes. In the second experiment, the application interval was the same as the pre-inoculation experiment, but with Fusarium inoculated first and then transferring bacteria to the substrate. The results of both experiments demonstrated that the Bacillus spp. application after the Fusarium installation, with and without time interval, proved to be the best biocontrol of this disease in Prata-Anã plants.

\section{Biocontrole de Fusarium oxysporum f. sp. cubense mediado por Bacillus spp.}

\section{em banana Prata-anã}

RESUMO: O objetivo desse estudo foi avaliar o efeito do controle de Bacillus spp. sobre à atividade do Fusarium oxysporum f. sp. cubense (Foc) em casa de vegetação. Dois experimentos foram organizados. 0 primeiro experimento consistiu na aplicação de Bacillus no substrato, com adição de Foc sete dias após; duas aplicações de Bacillus em intervalo de sete dias no substrato e aplicação de Foc sete dias após a última aplicação de Bacillus; Bacillus aplicado no substrato no mesmo momento que o Foc. Após 14 dias de incubação do substrato infestado por Foc e Bacillus, realizou-se o plantio das mudas de banana da cultivar Prata Anã em tubetes. No segundo experimento, o intervalo de aplicações foram os mesmos do experimento de pré-inoculação, porém o Fusarium foi inoculado no substrato da bactéria. Os resultados dos experimentos evidenciaram que a aplicação de Bacillus spp., após a instalação do Fusarium, com e sem intervalo de tempo, mostrou-se o melhor biocontrole dessa doença em plantas de Prata-Anã.

Palavras-chave: controle biológico; murcha de Fusarium; rizobactérias 


\section{Introduction}

Banana production is emphasized as an activity of great economic and social importance, cultivated in an extensive tropical region all over the world and, generally, by small producers. Banana production occupies the first position in the fruit world ranking. In the last census held, the world banana production was about 114 million tons, cultivated on a large scale by India, China, Indonesia and Brazil. The latter country, Brazil, ranks fourth as a global banana producer and produced approximately 6.67 million tons in 465 thousand hectares of cultivated area in 2017 (FAO, 2019), generating a Gross Production Value (VBP) close to 7.9 billion of reals (IBGE, 2019). The banana production has an extremely relevant social role for the country, fixing man in the field and generating jobs and income mainly for family farming, thus reinforcing the fruit importance for the Brazilian agribusiness (Borges et al., 2009).

Despite great advances in cultivation techniques, many diseases limit the banana production, with the Fusarium wilt as one of the most destructive diseases in this crop, caused by the fungus Fusarium oxysporum f. sp. cubense (Foc). This disease has a major destructive potential, and is able to result in losses of up to $100 \%$ in production, thus it is characterized as one of the most relevant phytosanitary problems on the banana production worldwide (Ploetz, 2015). The fungus species responsible for the disease includes a wide diversity of strains responsible for wilting or rot in many plant species (Lecomte et al., 2016). In Brazil, race 1 (Foc 1) causes serious damage in the main banana-producing regions and especially in cultivars from the "Prata" subgroup, such as the Prata-Anã, Prata Catarina and Prata Gorutuba, which altogether occupy more than $60 \%$ of the country cultivation area. In addition to this subgroup, the Silk type (cv. Maçã) is also susceptible to the Foc 1 race and, therefore, is becoming rare in local markets (Rebouças et al., 2018).

This pathology is endemic for all banana-producing regions in the world, and it has a complex controlling, as fungicides are not effective. Using resistant cultivars sets precedents for the emergence of new pathogen races, which classifies it, in terms of relevance to the banana production, in similar condition to the yellow and black Sigatoka leaf spots (Borges et al., 2009). The emergence of new races is one of the major global concerns among the banana producers, and as an example there is a new Foc variant, the tropical race 4 (Foc TR4), that led to the widespread destruction of plantations in Cavendish-producing areas all over the world, especially in China, Australia, Indonesia, Malaysia and the Philippines (Ploetz, 2015).

One of the great difficulties in controlling fungus is related to its survival structure, known as chlamydospores, which can remain in the soil with no host for several years. Once the pathogen is established on the soil, new plantations must be grown in disease-free areas so that it is possible to keep the banana production in a given region (Ploetz, 2015). This widespread loss of both production and arable land in the banana cultivation signalizes an urgent need in developing innovative and sustainable disease-prevention strategies for banana plantations, for both the current and future ones (Fu et al., 2017). Controlling measures such as using resistant cultivars (Gonçalves et al., 2019), fungicides and soil fumigation (Nel et al., 2007), as well as crop rotation (Wang et al., 2015) have been employed. However, biological control appears as a new, highly promising, strategy for controlling Foc, mainly due to its advantages in relation to the safety and conservation of the environment (Huang et al., 2019).

Biological control consists in purposely using living organisms that can be resident or introduced into diseasehost plants, having the suppression of the activities and populations of one or more plant pathogens as the objective. Rhizobacteria responsible for promoting the plant growth have been used for controlling plant pathogens and increasing the banana yield (Haddad et al., 2018).

The genus Bacillus spp. has stood out as phytopathogenic antagonist bacteria due to the formation of endospores and the variety of antagonistic mechanisms, allowing for both long-term support and survival in peculiar ecological niches, with great diversity regarding the action mechanisms for 'deceiving' the phytopathogens defenses.

Bacillus are able to efficiently compete for nutrients in the soil, increasing their microbial mass, releasing of various antimicrobial substances, root colonization and the strains ability in using nutrients for their own growth, thus affecting the Foc development (Fu et al. , 2017; Huang et al., 2019; Palyzová et al., 2019). It is noteworthy that the amount and composition of the root exudates produced by plants vary depending on the species, cultivar, age of individual plants, and on the external abiotic and biotic factors (Haichar et al., 2014).

To that end, the present study objective was to evaluate the bacterium-controlling capacity of the genus Bacillus in relation to the activity of the Fusarium oxysporum $\mathrm{f}$. $\mathrm{sp}$. cubense race 1 in the Prata-Anã cultivar, part from the 'Prata' subgroup.

\section{Materials and Methods}

The experiment was conducted under greenhouse conditions, from January 2016 to May of the same year, at Embrapa Cassava and Fruits located in Cruz das Almas, Ba (1240'19" S and 39006'22" W, altitude of $220 \mathrm{~m}$ above the sea). For producing the inoculum of Fusarium oxysporum sp. cubense race 1 , the CNPMF-0801 isolate, which is the standard used by Embrapa for selecting resistant genotypes both under greenhouse and field conditions, was used alongside the isolates of the genus Bacillus pre-selected for biological control assays, re-established in Petri dishes, both from the fungi collection of laboratories owned by Embrapa itself. The monosporic culture obtained was grown in nutrient agar and kept in a growth chamber at $25{ }^{\circ} \mathrm{C}$ with a 12-hour photoperiod.

In order to prepare the Foc inoculum, $1330 \mathrm{~g}$ of washed sand, $250 \mathrm{~g}$ of moist cornmeal and $150 \mathrm{~mL}$ of distilled water 
were all mixed. This resulting substrate was then placed in $500-\mathrm{cm}^{3}$ polypropylene bags and sterilized in an autoclave at $120^{\circ} \mathrm{C}$ for one hour. Disks from the culture medium containing mycelia and Foc conidia were added to the mixture, which was incubated in a growth chamber at 25 으 for 20 days for the inoculum multiplication. After this period, Foc colony-forming units (CFU) were accounted by using the serial dilution technique. $1 \mathrm{~g}$ from the mixture was used and placed in a test tube with $9 \mathrm{~mL}$ of distilled water and, subsequently, dilutions of $10^{-1}, 10^{-2}, 10^{-3}, 10^{-4}$ and $10^{-5}$ were performed. The last two dilutions $\left(10^{-4}\right.$ and $\left.10^{-5}\right)$ were subjected to multiplication in Petri dishes containing a BDA medium. The plates were kept in a growth chamber at $25^{\circ} \mathrm{C}$ for 48 hours for later counting the colony-forming units number.

The Bacillus spp. isolates were thus removed from the Petri dishes with the aid of a Drigalski loop and transferred to a Becker containing distilled water. After this procedure, $1.0 \mathrm{~mL}$ of this solution was transferred to test tubes for serial dilutions $\left(10^{-1}, 10^{-2}, 10^{-3}, 10^{-4}\right.$ and $\left.10^{-5}\right)$. Afterwards, a $0.1 \mathrm{~mL}$ aliquot from the last two dilutions $\left(10^{-4}\right.$ and 10 $\left.{ }^{5}\right)$ was transferred to Petri dishes containing nutrient agar, kept in a growth chamber at $37{ }^{\circ} \mathrm{C}$ for 48 hours with a 12 hour photoperiod for counting the colony-forming units (CFU), an adapted methodology of Rebouças et al. (2018). After determining the initial concentration of each bacterial suspension, they were diluted in distilled water until reaching a concentration of $10^{7} \mathrm{CFU} \mathrm{mL} \mathrm{m}^{-1}$. The absorbance reading, where the recommended for suspension of bacterial or yeast cells is in the range from 540 to $640 \mathrm{~nm}$, was performed by optical density in the spectrophotometer of the Microbiology Laboratory from Embrapa Cassava and Fruits.

For evaluating the effect of Bacillus in controlling Fusarium oxysporum f. sp. cubense (Foc) in banana plants of the Prata-Anã cultivar, previously isolated in a safe environment free from attack of pests and diseases, the experimental design used was the completely randomized (CRD), under greenhouse conditions, having three treatments with three controls and 10 replicates (one plant per experimental unit). We selected the Prata-Anã cultivar due to its importance for the Brazilian banana production, having this cultivar as the most widely grown in the Northeast region, the second-largest banana producer in Brazil (IBGE, 2019). Moreover, this cultivar behaves as a moderately susceptible material in relation to the Fusarium oxysporum f. sp. cubense (Foc), and thus, because of this, finding solutions to inhibit the action of the pathogen is of utmost importance for the banana production.

The experimental study was set up in two fronts, where the first experiment comprised the following: T1- one Bacillus application on the substrate, adding Foc seven days later; T2two Bacillus applications on the substrate (the first on day one and the second seven days later) and Foc application seven days after the second Bacillus application; T3-Bacillus and Foc simultaneously applied on the substrate. The control groups were composed of substrate infestation only with Bacillus (C1), only with Foc (C2) and no substrate inoculation (C3). After 14 days of incubation of the substrate inoculated with Foc and Bacillus, the banana seedlings were planted in tubes.

In the second experiment, the application interval was the same as in the pre-inoculation experiment, but this time the Fusarium was inoculated first and the bacteria was applied to the substrate later. The following treatments were applied: T1- one Foc application on the substrate, adding Bacillus seven days later; T2- two Foc applications on the substrate (the first on day one and the second after seven days) and Bacillus application seven days after the second Foc application; T3Foc and Bacillus simultaneously applied on the substrate. The control groups were composed of substrate infestation only with Bacillus (C1), only with Foc (C2) and no substrate inoculation (C3), as Table 1 also illustrates.

Six evaluations were performed at intervals of 15 days, with the first external evaluation held at 15 days after planting, employing the grading scale proposed by Cordeiro et al. (2016), totaling 90 evaluation days. Plants were kept in the greenhouse with temperature of approximately $26^{\circ} \mathrm{C}$. The following variables were evaluated: number of leaves; plant height $(\mathrm{cm})$, measured from the pseudostem base to the last fully open leaf; pseudostem diameter $(\mathrm{cm})$, measured with the aid of a caliper; and finally, the disease severity index (ID $\%)$ was calculated.

Measurements associated with internal symptoms at the end of 90 days were performed from the cross section of the rhizome for analyzing the vascular discoloration caused by the

Table 1. Distribution of the different treatments applied on the substrate with the Prata-Anã cultivar. Embrapa, 2016.

\begin{tabular}{cl}
\hline Experiment 1 & \multicolumn{1}{c}{ Methods } \\
\hline T1* & One Bacillus application on the substrate, with Foc addition seven days after applying Bacillus \\
T2 & Two Bacillus applications on the substrate and Foc application seven days after the second Bacillus application \\
T3 & Bacillus and Foc simultaneously applied on the substrate \\
C1 & Substrate infestation only with Bacillus \\
C2 & Only with Foc \\
\hline C3 & No substrate inoculation \\
\hline Experiment 2 & One Foc application on the substrate, with Bacillus application seven days after applying Foc \\
\hline T1* & Two Foc applications on the substrate and Bacillus application seven days after the second Foc application \\
\hline T3 & Bacillus and Foc simultaneously applied on the substrate \\
C1 & Substrate infestation only with Bacillus \\
C2 & Only with Foc \\
C3 & No substrate inoculation \\
\hline
\end{tabular}

*Experiment 1 (using Bacillus before applying Foc); **Experiment 2 (applying Foc before applying Bacillus); Control (C); Treatment (T). 
Foc presence. Based on the scale proposed by Cordeiro et al. (2016) and cited by Gonçalves et al. (2019), the plants received the following notes: (1) absence of vascular discoloration, healthy plant; (2) isolated discoloration spots in the vascular cambium; (3) discoloration in $1 / 3$ of the vascular cambium; (4) discoloration between $1 / 3$ and $2 / 3$ of the vascular cambium; (5) discoloration over $2 / 3$ of the vascular cambium; and (6) complete discoloration of the vascular cambium. Afterwards, the disease severity index (ID) was transformed by Mckinney expression (1923) - Equation 1.

$$
\mathrm{ID}=\sum \frac{(\text { scale degree } \times \text { frequency })}{(\text { total no. of units } \times \text { maximum scale degree })} \times 100
$$

As for the statistical analysis, the disease severity index (ID) was estimated from the scale of external and internal symptoms, respectively, obtained through three replicates (two composed by data from three plants and another one composed by four plants ). The data obtained were subjected to analysis of variance (ANOVA) and the means were compared with the Tukey test, at the level of $5 \%$ probability, using the SISVAR statistical program (Ferreira, 2011). The disease severity index data were transformed into $\sqrt{ } x+0.5$.

\section{Results and Discussion}

There were significant differences for the source of variation between the 'treatments' (Table 2). The height, pseudostem diameter and number of leaves of the plants submitted to the three treatments and three controls, referring to the first experiment in which Bacillus was applied before Foc, show different results both among variables and between treatments and controls.

Analyzing only the plant height between treatments variable, it is evident that treatment T2 (two Bacillus applications on the substrate and Foc application seven days later) stood out. It is noteworthy that this greenhouse experiment differs from methods aimed at field experiments, not striving for plants with smaller heights, as recommended by the literature, but for greater efficiencies among treatments in inhibiting and/or controlling the Foc.

As for the number of leaves of the plant and the pseudostem diameter in experiment 1, only the T1 treatment differed from the others, having a lower value than them, where ranging from 1.90 (T1) to 4.60 (T3) for number of leaves and from $0.40 \mathrm{~cm}$ (T1) to $1.08 \mathrm{~cm}$ (T2) for pseudostem diameter (Table 2). However, regarding the disease index, the T1 treatment, in which Bacillus and Foc were inoculated with a time interval, demonstrated a higher value, indicating that one Bacillus application was not efficient in controlling the disease. A sufficient Bacillus colonization in the rhizosphere is considered a key point in exhibiting the beneficial effects caused by the bacteria (Yuan et al., 2018).

Regarding the control, there were no significant differences among C1, C2 and C3 on the number of leaves and pseudostem diameter variables, which was not expected, since plants with an incidence or severity of Fusarium wilt tend to have lower numbers of leaves and a more fragile and reduced pseudostem (Cavatte et al., 2012; Gonçalves et al., 2019). The study of the number of leaves and the pseudostem diameter are directly related to the production, as the number of live leaves has a positive relation with the fruit weight gain, since a greater photosynthetic efficiency will help in a greater weight production of the bunch. The pseudostem diameter, on the other hand, is related to its tipping and breaking caused by the wind action, thus providing greater vigor and resistance in sustaining the bunch, with plants with greater sustaining capacity tending in supporting a larger bunch, minimizing the banana growers losses and justifying these two variables in our study (Cavatte et al., 2012).

The treatments T2 of experiment 1 (two Bacillus applications of and one of Foc) and T3 (Bacillus and Foc application with no time interval) had the lowest disease rates, showing that, in these cases, Bacillus is able to inhibit Foc development, with these two treatments as the most efficient in inhibiting the Foc growth. These results suggest that the Bacillus application on the soil, before planting the banana seedlings, can decrease the inoculum amount in the soil and prevent the disease, impeding Foc from spreading. Studies point out that the action of Bacillus on Fusarium is related to the amount of the antagonist in the rhizosphere region, which ensures that it competes with the pathogen more effectively (Palyzová et al., 2019).

Most strains need to penetrate effectively, host and establish endophytic associations so that they can play a better role in the biological control, so the strategic endophytes application before transplantation or invasion of pathogens increases the biocontrol capacity (Su et al., 2017).

Studies conducted with Fusarium oxysporum f. sp. radicislycopersici (Forl) in tomato plants indicated that treatments

Table 2. Test of means between three agronomic characteristics and disease severity index (ID) in the Prata-Anã cultivar infested by Bacillus and later by Fusarium oxysporum f. sp. cubense (Foc) under controlled environment conditions. Embrapa, 2016.

\begin{tabular}{ccccc}
\hline Treatment & Height $(\mathbf{c m})$ & Number of leaves & Diameter $(\mathbf{c m})$ & ID $^{\mathbf{1}}(\%)$ \\
\hline T1 & $27.50 \mathrm{~b}^{*}$ & $1.90 \mathrm{~b}$ & $0.40 \mathrm{~b}$ & $31.11 \mathrm{a}$ \\
T2 & $29.90 \mathrm{ab}$ & $4.30 \mathrm{a}$ & $1.08 \mathrm{a}$ & $16.67 \mathrm{~b}$ \\
T3 & $27.50 \mathrm{~b}$ & $4.60 \mathrm{a}$ & $1.05 \mathrm{a}$ & $10.00 \mathrm{~b}$ \\
C1 & $28.40 \mathrm{~b}$ & $5.10 \mathrm{a}$ & $0.93 \mathrm{a}$ & $0.00 \mathrm{c}$ \\
C2 & $30.20 \mathrm{ab}$ & $4.70 \mathrm{a}$ & $0.97 \mathrm{a}$ & $30.56 \mathrm{a}$ \\
C3 & $31.50 \mathrm{a}$ & $4.20 \mathrm{a}$ & $0.94 \mathrm{a}$ & $0.00 \mathrm{c}$ \\
\hline
\end{tabular}

T1 - Bacillus + Foc with interval; T2 - Bacillus + Bacillus + Foc with interval; T3 - Bacillus + Foc with no interval; C1 - Only Bacillus; C2 - Only Foc; C3 - No infestation. *Means followed by the same lowercase letter, in the column, do not differ from each other by the Tukey test at $5 \%$ probability. ${ }^{1}$ Data from non-transformed original ID. 


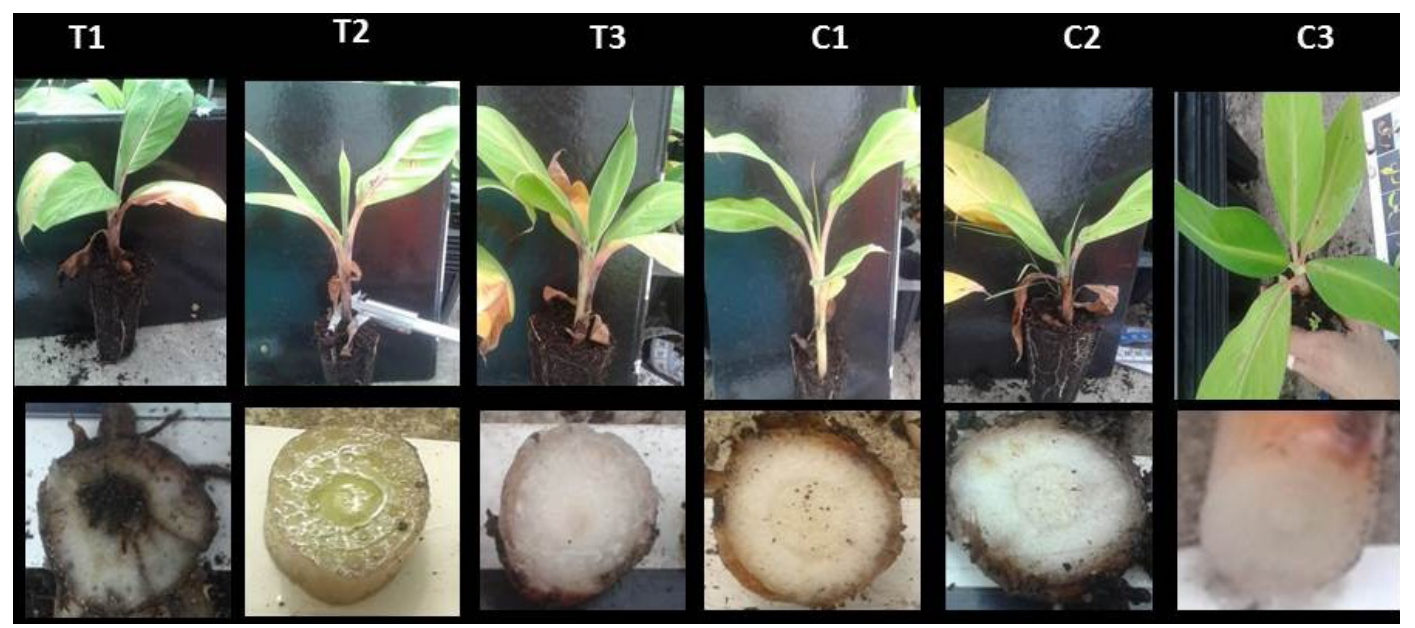

Figure 1. External and internal symptoms of Fusarium wilt, with Bacillus previously applied to Fusarium oxysporum f. $\mathrm{sp}$. cubense in the Prata-Anã cultivar. T1- one Bacillus application on the substrate, with the Foc addition seven days later; T2- two Bacillus applications on the substrate (the first on day one and the second seven days later) and Foc application seven days after the second Bacillus application; T3- Bacillus and Foc applied simultaneously to the substrate. The controls were composed by infestation of the substrate only with Bacillus (C1), only with Foc (C2) and with no inoculation on the substrate (C3). After an incubation period of 14 days of the substrate inoculated by Foc e Bacillus.

with single applications of the biocontrol agent at the sowing time, regardless of the dose, did not provide high control of the disease, possibly due to the decline of the developing bacterial population on the root surface (Samaras et al., 2018), which may have occurred in the present study.

In experiment 2, in which Bacillus was applied after Fusarium when analyzing the plant height variable, the T2 treatment stands out with a value greater than $28.0 \mathrm{~cm}$, thus demonstrating that the double Foc application on the substrate did not hinder the plant growth and that applying Bacillus after Foc proved to be more efficient under these conditions. Regarding the controls, none of them stood out (Table 3). Even with the presence of the disease or with only Bacillus, the plants had an equal growth. As for the number of leaves, the treatments $\mathrm{T} 1, \mathrm{~T} 2$ and $\mathrm{T} 3$ did not differ, in other words, the application of Foc with Bacillus once or twice, with or without interval, did not interfere in the results. The Foconly control (C2) had a lower value when compared to the others regarding the number of leaves variable, indicating that the fungus had a negative effect on it and its development in the Prata-Anã cultivar.

For the parameter pseudostem diameter, there is no significant difference between treatments and controls, thus stating that Foc does not influence the pseudostem thickness variable, at least not in the plant early life stages (Table 3).

T1 and T3 treatments, with Bacillus application with and without time interval, effectively controlled the Fusarium pathogen having a zero ID. Studies indicate that the phenolics secretion of root, such as the ortho-phthalic acid, salicylic acid and cinnamic acid, was increased in Focinfected banana seedlings. Through the exudation of a wide variety of compounds, the roots can regulate the soil microbial community (Haichar et al., 2014). Organic acids with low molecular weight are important components in root exudates, as signals or nutrients, released in the few millimeters of soil around the root. These phenolic acids present in banana root exudates can enhance the roots colonization ability of Bacillus amyloluquefaciens NJN-6, as well as its ability in suppressing Fusarium (Yuan et al., 2018). However, it is noteworthy that when Fusarium was applied twice on the substrate, thus increasing its concentration in the medium, the subsequent Bacillus application was not efficient in controlling the disease, resulting in a higher disease rate. This indicates that in soils too infested with Foc, the possibility of increasing the Bacillus application, before planting banana, would be the most viable control, serving as a method of preventing the Foc advance in certain areas

Table 3. Test of means with three agronomic characteristics and the disease severity index (ID) in the Prata-Anã cultivar infested by Fusarium oxysporum f. sp. cubense (Foc) and then by Bacillus under controlled environment conditions. Embrapa 2016.

\begin{tabular}{ccccc}
\hline Treatment & Height $(\mathbf{c m})$ & Number of leaves & Diameter $(\mathbf{c m})$ & ID $^{\mathbf{1}}(\%)$ \\
\hline T1 & $24.00 \mathrm{~b}^{*}$ & $3.90 \mathrm{bc}$ & $1.00 \mathrm{a}$ & $0.00 \mathrm{c}$ \\
T2 & $28.60 \mathrm{a}$ & $4.40 \mathrm{ab}$ & $1.06 \mathrm{a}$ & $56.11 \mathrm{a}$ \\
T3 & $24.40 \mathrm{~b}$ & $4.00 \mathrm{ab}$ & $1.78 \mathrm{a}$ & $0.00 \mathrm{c}$ \\
$\mathrm{C} 1$ & $23.70 \mathrm{~b}$ & $4.70 \mathrm{ab}$ & $1.02 \mathrm{a}$ & $0.00 \mathrm{c}$ \\
$\mathrm{C} 2$ & $22.80 \mathrm{~b}$ & $3.10 \mathrm{c}$ & $1.00 \mathrm{a}$ & $24.44 \mathrm{~b}$ \\
$\mathrm{C} 3$ & $24.80 \mathrm{~b}$ & $4.80 \mathrm{a}$ & $1.03 \mathrm{a}$ & $0.00 \mathrm{c}$ \\
\hline
\end{tabular}

T1 - Bacillus + Foc with interval; T2 - Foc + Foc + Bacillus with interval; T3 - Foc + Bacillus with no interval; C1 - Only Bacillus; C2 - Only Foc; C3 - No infestation. * Means followed by the same lowercase letter, in the column, do not differ from each other by the Tukey test at $5 \%$ probability. ${ }^{1}$ Data from non-transformed original ID. 


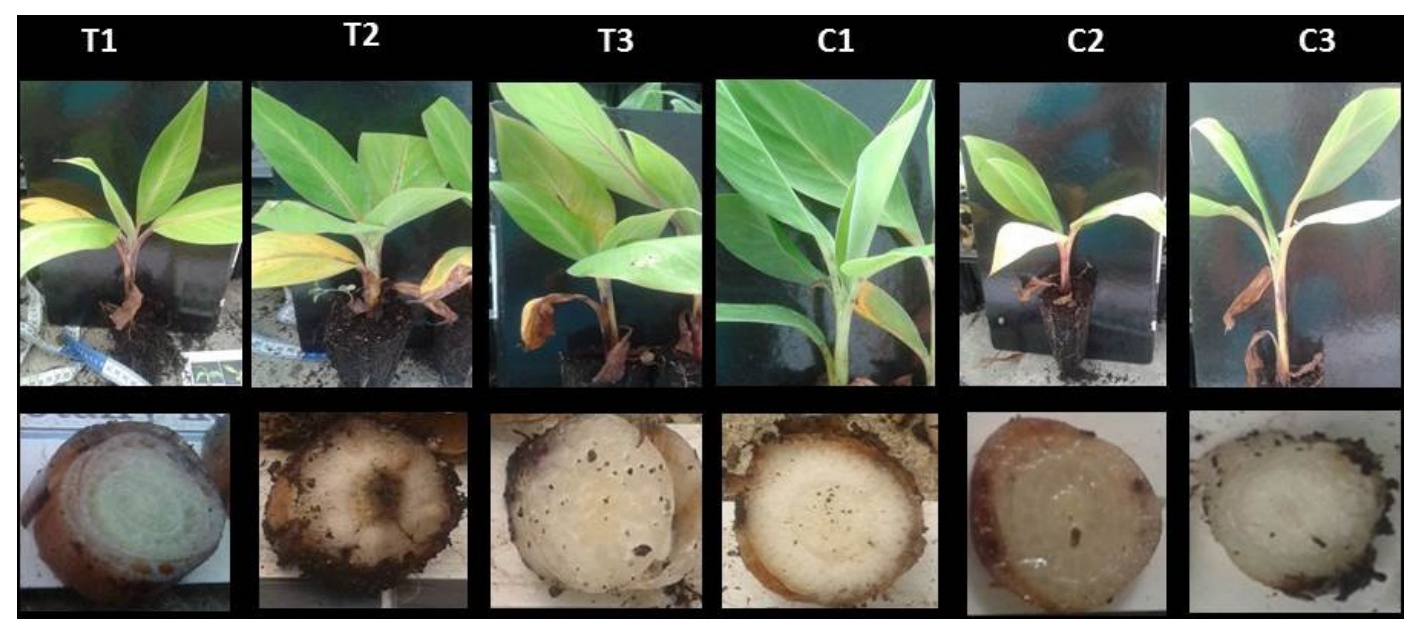

Figure 2. External and internal symptoms of the Panama disease, from the second experiment after evaluating the interaction Fusarium oxysporum f. sp. cubense and Bacillus in the Prata-Anã cultivar. T1- one Foc application on the substrate, with the Bacillus application seven days later; T2- two Foc applications on the substrate (the first on day one and the second seven days later) and Bacillus application seven days after the second Foc application; T3- Foc and Bacillus applied simultaneously to the substrate. The controls were composed of infestation of the substrate with only Bacillus (C1), only Foc (C2) and no inoculation (C3).

of banana plantations, mainly those considered as more susceptible to the attack of this fungal disease.

The progressive yellowing of the older leaves and reddishbrown punctuation in the pseudostem, most often due to the oxidation of phenols in the T2 treatment plants and in the C2 control, demonstrated the disease severity degree, was not visible in other treatments (Figure 2). According to Cordeiro et al. (2016), Foc infection causes a progressive yellowing from the older leaves to the younger ones, starting from the leaf blade edges to the main vein, with subsequent leaf wilting and breaking next to the pseudostem, a behavior that was not observed in this study.

These results are determined by Bacillus acting, in an antagonistic way, directly against phytopathogens, which comprises antibiosis mechanisms, where one organism harms the other, such as the following: production of antimicrobial substances, formation of volatile compounds, as well as the competition for nutrients and space (Palyzová et al., 2019; Huang et al., 2019). Foc accumulation results in the segregation of toxins that attack the banana tree roots, spreading to the pseudostem and leaves, thus resulting in the Fusarium wilt. The banana tree growth is closely related to the rhizosphere biodiversity (Fu et al., 2017).

Bacillus can compete for nutrients in the soil, thus affecting the chlamydospore development of the pathogen (Huang et al., 2019) and competing with it in the root infection sites, in addition to triggering the plant defense reactions, inducing the systemic resistance or the acquired defense (Gang et al., 2013). However, previous studies point out that the increase in microbial biomass is favorable to the development of the fungus general suppression and, consequently, of the disease. This is due to the increased competition for resources and interactions that reduce the infecting and establishing abilities of soil pathogens (Fu et al., 2017). Therefore, it is important to study the ideal amount of antagonistic bacteria so that there is an important effect on the fungus suppression, as verified in the present study. Hence, new studies with new applications of Bacillus spp. can be conducted, but having the seedling planted at the same time that the treatments are applied, or by adding the formulations before planting, but emphasizing that treatments applied as soon as the Foc infects the soil further reduces the disease rate. The application of Bacillus spp., after Fusarium setting up, with and without a time interval, proved to be the best treatment as a biocontrol of the Fusarium wilt in Prata-Anã banana plants.

Bacillus amyloliquefaciens is famous for biocontrolling soil-borne diseases and its main involved mechanisms are antibiosis, competition, growth promotion and induction of systemic resistance. However, the effects of Bacillus spp. that were desired were not observed in many field application situations. It is known that plant root exudates secrete a wide variety of compounds to mediate interactions between microorganisms in the rhizosphere (Haichar et al., 2014). Alteration of the compounds in the banana root exudates with Foc infection may further induce the further biofilm formation on Bacillus spp. strains, as well as inducing the genes involved in the bacterium antibiotics production (Yuan et al., 2018). This occurred in all treatments of experiment 2, because Foc. when inoculated first than Bacillus spp. induces the production of these compounds as soon as it comes in contact with the banana tree roots.

It is worth nothing that these treatments must be performed in field or in infested areas in order to be validated. However, prior to this, a new evaluation is indicated as to the ideal dosage of Bacillus application for controlling Foc in the soil and/or the substrate, mindful of which banana cultivar is grown in the area and which is pathogen concentration in this same location. Moreover, more profound studies are necessary for evaluating the technical feasibility of the field treatments. 


\section{Conclusions}

Using Bacillus spp. is favorable to the biological control of Fusarium wilt in the Prata-Anã banana cultivar.

Applying Bacillus spp. after setting Fusarium up, with and without time interval, proved to be the best biocontrol for this disease in Prata-Anã banana plants.

The used concentration of Bacillus spp. was not effective in inhibiting a high Fusarium concentration.

\section{Literature Cited}

Borges, A.L.; Souza, L.S.; Oliveira, A.M.G. Banana. In: Crisostomo, L. A.; Naumov, A. (Orgs.). Adubando para alta produtividade e qualidade: fruteiras tropicais do Brasil. Fortaleza: Embrapa Agroindústria Tropical; Horgen: Instituto Internacional de Potassa, 2009. 238p. (Embrapa Agroindústria Tropical. Boletim, 18). http://ainfo.cnptia.embrapa.br/digital/bitstream/ item/34419/1/LV09002.pdf. 05 Nov. 2019.

Cavatte, R. P. Q.; Salomão, L.; Siqueira, D.; Peternelli, L.; Cavate, P. Redução do porte e produção das bananeiras 'Prata-Anã' e 'FHIA01 ' tratadas com paclobutrazol. Revista Brasileira de Fruticultura, v.34, n.2, p.356-365, 2012. https://doi.org/10.1590/S010029452012000200007.

Cordeiro, Z.J.M.; Matos, A.D.; Haddad, F. Doenças fúngicas e bacterianas. In: Ferreira, C. F.; Silva, S. de O. e; Amorim, E. P.; Santos-Serejo; J. A. de. (Eds.). O agronegócio da banana. 1.ed. Brasília: Embrapa, 2016. Cap. 16, p.547-575.

Food and Agriculture Organization - FAO. Production crop data. http://www.fao.org/faostat/en/\#data . 10 Out. 2019.

Ferreira, D.F. Sisvar: a computer statistical analysis system. Ciência e Agrotecnologia, v. 35, n.6, p. 1039-1042, 2011. https://doi. org/10.1590/S1413-70542011000600001.

Fu, L.; Penton, C.R.; Ruan, Y.; Shen, Z.; Xue, C.; Li, R.; Shen, Q. 2017. Inducing the rhizosphere microbiome by biofertilizer application to suppress banana Fusarium wilt disease. Soil Biology and Biochemistry, v.104, p.39-48. https://doi.org/10.1016/j. soilbio.2016.10.008.

Gang, G.; Bizun, W.; Weihong, M.; Xiaofen, L.; Xiaolin, Y.; Chaohua, Z.; Jianhong, M.; Huicai, Z. Biocontrol of Fusarium wilt of banana: Key influence factors and strategies. African Journal of Microbiology Research, v.7, n.41, p.4835-4843, 2013 https://doi.org/10.5897/ AJMR2012.2392.

Gonçalves, Z.S.; Haddad, F.; de Oliveira Amorim, V.B.; Ferreira, C.F.; de Oliveira, S.A.S.; Amorim, E.P. Agronomic characterization and identification of banana genotypes resistant to Fusarium wilt race 1. European Journal of Plant Pathology, v.155, p.1-11, 2019. https://doi.org/10.1007/s10658-019-01837-5.

Haddad, F.; Rocha, L.S.; Soares, A.C.F.; Martins, I.P.S.; Teixeira, L.A.J.; Staver, C.; Dita, M. Management of Fusarium wilt of bananas in Minas Gerais, Brazil. Acta Horticulture, v. 1196, p.137-146, 2018. https://doi.org/10.17660/ActaHortic.2018.1196.16.

Haichar, F.E.Z.; Santaella, C.; Heulin, T.; Achouak, W. Root exudates mediated interactions belowground. Soil Biology and Biochemistry, v.77, p.69-80, 2014. https://doi.org/10.1016/j. soilbio.2014.06.017.
Huang, J.; Pang, Y.; Zhang, F.; Huang, Q.; Zhang, M.; Tang, S.; Fu, H.; $\mathrm{Li}$, P. Suppression of Fusarium wilt of banana by combining acid soil ameliorant with biofertilizer made from Bacillus velezensis H-6. European Journal of Plant Pathology, v.154, p.585-596, 2019. https://doi.org/10.1007/s10658-019-01683-5.

Instituto Brasileiro de Geografia e Estatística - IBGE. Levantamento sistemático da Produção Agrícola - LSPA. Produção Agrícola Lavoura Permanente. Banana. https://cidades.ibge.gov.br/brasil/ pesquisa/15/0?indicador=11884\&ano=2017. 08 Jan. 2019.

Lecomte, C; Alabouvette, C; Edel-Hermann, V; Robert, F; Steinberg, C. Biological control of ornamental plant diseases caused by Fusarium oxysporum: a review. Biological Control, v.101, p.17-30, 2016. https://doi.org/10.1016/j.biocontrol.2016.06.004.

McKinney, H.H. Influence of soil, temperature and moisture on infection of wheat seedlings by Helminthosporium sativum. Journal of Agricultural Research, v.26, n.5, p.195-217, 1923.

Nel, B.; Steinberg, C.; Labuschagne, N.; Viljoen, A. Evaluation of fungicides and sterilants for potential application in the management of Fusarium wilt of banana. Crop Protection, v.26, n.4, p.697-705, 2007. https://doi.org/10.1016/j. cropro.2006.06.008.

Palyzová, A.; Svobodová, K.; Sokolová, L.; Novák, J.; Novotný, Č. Metabolic profiling of Fusarium oxysporum f. sp. conglutinans race 2 in dual cultures with biocontrol agents Bacillus amyloliquefaciens, Pseudomonas aeruginosa, and Trichoderma harzianum. Folia Microbiologica, p.1-9, 2019. https://doi. org/10.1007/s12223-019-00690-7.

Ploetz, R.C. Management of Fusarium wilt of banana: A review with special reference to tropical race 4. Crop Protection, v.73, p.7-15, 2015. https://doi.org/10.1016/j.cropro.2015.01.007.

Rebouças, T.A.; Haddad, F.; Ferreira, C.F.; de Oliveira, S.A.S.; da Silva Ledo, C.A.; Amorim, E.P. Identification of banana genotypes resistant to Fusarium wilt race 1 under field and greenhouse conditions. Scientia Horticulturae v.239, p.308-313, 2018. https://doi.org/10.1016/j.scienta.2018.04.037.

Samaras, A.; Efthimiou, K.; Roumeliotis, E.; Karaoglanidis, G.S. Biocontrol potential and plant-growth-promoting effects of Bacillus amyloliquefaciens MBI 600 against Fusarium oxysporum f. sp. radicis-lycopersici on tomato. Acta Horticulturae, v.1207, p.139-146, 2018. https://doi.org/10.17660/ ActaHortic.2018.1207.18.

Su, L.; Shen, Z.; Ruan, Y.; Tao, C.; Chao, Y.; Li, R.; Shen, Q. Isolation of antagonistic endophytes from banana roots against Meloidogyne javanica and their effects on soil nematode community. Frontiers in Microbiology, v.8, article 2070, 2017. https://doi.org/10.3389/ fmicb.2017.02070.

Wang, B.; Li, R.; Ruan, Y.; Ou, Y.; Zhao, Y.; Shen, Q. Pineapple-banana rotation reduced the amount of Fusarium oxysporum more than maize-banana rotation mainly through modulating fungal communities. Soil Biology and Biochemistry, v.86, p.77-86, 2015. https://doi.org/10.1016/j.soilbio.2015.02.021.

Yuan, J.; Wu, Y.; Zhao, M.; Wen, T.; Huang, Q.; Shen, Q. Effect of phenolic acids from banana root exudates on root colonization and pathogen suppressive properties of Bacillus amyloliquefaciens NJN-6. Biological Control, v.125, p.131-137, 2018. https://doi. org/10.1016/j.biocontrol.2018.05.016. 